\title{
Haematobiochemical and Mineral Level Changes in Microfilaraemic Dogs
}

\author{
Jaydip R. Patel ${ }^{1}$, Sarita Devi ${ }^{1}$ *, J.P. Varshney ${ }^{2}$, S.H. Raval ${ }^{1}$, \\ V.N. Sarviya ${ }^{3}$ and K.M. Jadhav ${ }^{1}$ \\ ${ }^{1}$ Department of Pathology, CoVSc \& AH, SDAU, Sardarkrushinagar, Gujarat -385506, India \\ ${ }^{2}$ Veterinary Medicine Consultant, Nandini Veterinary Hospital, Surat, Gujarat, India \\ ${ }^{3}$ Department of Pharmacology and Toxicology, CoVSc \& AH, SDAU, Sardarkrushinagar, \\ Gujarat -385506, India \\ *Corresponding author:
}

\section{A B S T R A C T}

K e y w o r d s
Hemato-
biochemical,
Mineral profile,
Dog, Microfilariae,
Dirofilaria immitis,
Dipetalonema
reconditum.

\section{Introduction}

Filariasis is one of the most important life threatening parasitic disease affecting canines having worldwide distribution. In India, presence of Dirofilaria immitis, Acanthocheilonema reconditum, Acanthocheilonema dracunculoides, Brugia malayi, Brugia ceylonesis and Brugia pahangi have been reported in canines (Ananda et al.,
2006). Amongst them D. immitis commonly referred to as heart worm of dogs is most pathogenic, having zoonotic potential too (Miyoshi et al., 2006). Adult worms are usually located in the right ventricle and pulmonary arteries (Quinn et al., 1998) leading to right ventricular hypertrophy (McCall et al., 2008; Seiler et al., 2010). Clinical manifestations of canine heartworm disease include cough, dyspnoea, weight loss, 
poor exercise tolerance, weakness, haemoptysis, cyanosis and congestive heart failure (Kramer, 2009; Cardoso et al., 2012). Depending upon the worm load, in situ transfer of nutrients from the tissues of the animal body to the parasites contributes to deficiency of organic and inorganic nutrients (Sharma and Pachauri, 1982; Sharma et al., 1985). The present study deals with the haemato-biochemical alterations and mineral level changes in dogs suffering from filariasis. Haemato-biochemical abnormalities are valuable in evaluating the progression of the disease in affected dogs.

\section{Materials and Methods}

A total of 418 clinical cases of dogs from the area of North Gujarat (TVCC, Deesa), South Gujarat (Nandini Veterinary Hospital, Surat) and Central Gujarat (private clinics, Ahmedabad) during July 2016 to May 2017 formed the basis of the research material.

\section{Modified Knott Technique (MKT)}

All the 418 clinical cases of dogs suspected for parasetemia were subjected to modified Knott's technique (MKT) as per standard procedures to detect circulating microfilariae (Castillo and Guerrero, 2006).

\section{Haemato-biochemical analysis}

Blood samples were collected from 33 dogs found positive for circulating microfilariae through MKT. Haematological analysis was performed from $\mathrm{K}_{3}$ EDTA whole blood using blood auto analyzer (Exigo EOS, Sweden). The hematological parameters included total erythrocyte count (TEC), total leukocyte count (TLC), Hemoglobin (Hb), hematocrit (HCT), platelets, eosinophils, monocyte, granulocyte and lymphocyte. From the serum sample, total protein (TP), albumin, globulin, aspartate aminotransferase (AST), alanine aminotransferase (ALT), total cholesterol, calcium $(\mathrm{Ca})$, magnesium $(\mathrm{Mg})$ and zinc $(\mathrm{Zn})$ were estimated according to manufacturer instructions (Agappe Diagnostics LTD, Ernakulam, Kerala, India) using auto analyzer (Randox Monaco, UK).

\section{Estimation of Zinc}

Estimation of $\mathrm{Zn}$ was done using (Atomic Absorption Spectroscopy (AAS). Serum samples were digested as per procedure (Devi et al., 2017). For that an aliquot of $1 \mathrm{ml}$ of serum was mixed with $10 \mathrm{ml}$ of triple acid mixture (Perchloric acid: Sulphuric acid: Nitric acid= 1:2:4) and the samples were kept overnight at room temperature before digestion on low heat $\left(70-80^{\circ} \mathrm{C}\right)$ using digestion bench. Digestion was carried out until the volume of samples was reduced to about $1 \mathrm{ml}$ or till the digested samples became watery clear and emits white fumes. The process was repeated for several times to get desired level of digestion and the volume of digested materials was reduced to approximately $0.5 \mathrm{ml}$ with slow heating. Final last volume was adjusted to $10 \mathrm{ml}$ with triple distilled deionized water.

\section{Statistical analysis}

The obtained data in this study was computed for mean values of different parameters studies and statistically analyzed by one way ANOVA Test using SPSS software (version 23.0).

\section{Results and Discussion}

The haematological changes recorded in the present study are given in Table 1 . The present study indicated highly significant $(\mathrm{p} \leq 0.01)$ decrease in $\mathrm{Hb}$ concentration and, increase in lymphocyte percentage in $D$. immitis group and similar non significant changes were recorded in $D$. reconditum group. The 
recorded reduction in the level of hemoglobin might be due to mechanical disruption of red blood cells due to presence of large numbers of adult heartworms in the right atrium and venae cavae, obstructing blood flow, causing intravascular haemolysis which further leads to decrease in the TEC, PCV, decreased erythrocytes fragility and platelets count as well. A previous hematological study in heart worm infected dogs also revealed low $\mathrm{Hb}$ concentration, increased erythrocyte sedimentation rate (ESR) and lymphocyte percentage (Sharma and Pachauri, 1982). Lymphocytosis is an indicative of chronic infestation with the filarial worm.

Highly significant $(p \leq 0.01) \quad$ decrease in platelet count and monocyte percentage and, increase in eosinophil count was observed in both the groups as compared to control. The rise in the eosinophil count is indicative of body defensive response to parasitaemia.

Table.1 Haematological Values of Microfilaraemic and Healthy Dogs (Mean \pm SE)

\begin{tabular}{|c|c|c|c|}
\hline Parameter & $\begin{array}{c}\text { Dirofilaria immitis } \\
(\mathbf{n = 1 0})\end{array}$ & $\begin{array}{c}\text { Dipetalonema reconditum } \\
(\mathbf{n = 2 3})\end{array}$ & $\begin{array}{c}\text { Control } \\
(\mathbf{n = 1 0})\end{array}$ \\
\hline RBC $\left(10^{6} / \mu \mathrm{l}\right)$ & $6.54 \pm 0.39$ & $6.53 \pm 0.33$ & $6.79 \pm .39$ \\
\hline WBC $\left(10^{3} / \mu \mathrm{l}\right)$ & $11.76 \pm 2.07$ & $13.36 \pm 1.14$ & $11.91 \pm 0.53$ \\
\hline Haemoglobin $(\mathrm{gm} / \mathrm{dl})$ & $10.46 \pm 0.82^{* *}$ & $14.67 \pm 0.83$ & $15.52 \pm 0.82$ \\
\hline HCT $(\%)$ & $43.45 \pm 3.21$ & $44.03 \pm 2.35$ & $48.47 \pm 1.90$ \\
\hline Platelets $\left(10^{3} / \mu \mathrm{l}\right)$ & $254.70 \pm 52.63^{* *}$ & $219.60 \pm 24.14 * *$ & $450.20 \pm 29.39$ \\
\hline Eosinophils $(\%)$ & $11.38 \pm 1.09^{* *}$ & $9.14 \pm 0.79^{* *}$ & $5.81 \pm 0.65$ \\
\hline Monocyte $(\%)$ & $3.21 \pm 0.19^{* *}$ & $3.06 \pm 0.24^{* *}$ & $5.96 \pm 0.84$ \\
\hline Granulocyte $(\%)$ & $69.85 \pm 3.96$ & $75.71 \pm 2.64$ & $70.76 \pm 3.44$ \\
\hline Lymphocyte $(\%)$ & $22.20 \pm 3.21^{* *}$ & $16.76 \pm 2.31$ & $10.01 \pm 0.71$ \\
\hline
\end{tabular}

$* \mathrm{P} \leq 0.05$ Significant $* * \mathrm{P} \leq 0.01$ Highly significant

Table.2 Serum Biochemical Values of Microfilaraemic and Healthy Dogs (Mean \pm SE)

\begin{tabular}{|c|c|c|c|}
\hline Parameter & $\begin{array}{c}\text { Dirofilaria immitis } \\
(\mathbf{n = 1 0})\end{array}$ & $\begin{array}{c}\text { Dipetalonema } \\
\text { reconditum } \\
(\mathbf{n = 2 3})\end{array}$ & Control $(\mathbf{n}=\mathbf{1 0})$ \\
\hline ALT $(\mathrm{U} / \mathrm{L})$ & $52.94 \pm 10.48$ & $56.04 \pm 4.08$ & $66.42 \pm 10.16$ \\
\hline AST $(\mathrm{U} / \mathrm{L})$ & $44.54 \pm 11.59$ & $60.37 \pm 6.66$ & $50.09 \pm 8.89$ \\
\hline Total Protein $(\mathrm{g} / \mathrm{dl})$ & $14.10 \pm 0.57^{* *}$ & $13.39 \pm 0.66^{* *}$ & $6.52 \pm 0.26$ \\
\hline Albumin $(\mathrm{g} / \mathrm{dl})$ & $2.62 \pm 0.11$ & $2.67 \pm 0.10$ & $2.46 \pm 0.15$ \\
\hline Globulin $(\mathrm{g} / \mathrm{dl})$ & $11.48 \pm 0.64^{* *}$ & $10.72 \pm 0.59^{* *}$ & $4.16 \pm 0.29$ \\
\hline Total Cholesterol $(\mathrm{mg} / \mathrm{dl})$ & $167.59 \pm 24.93$ & $206.63 \pm 10.11$ & $205.63 \pm 11.06$ \\
\hline $\mathbf{C a}(\mathrm{mg} / \mathrm{dl})$ & $8.47 \pm 0.40$ & $9.57 \pm 0.31^{* *}$ & $8.00 \pm 0.60$ \\
\hline $\mathbf{M g}(\mathrm{mg} / \mathrm{dl})$ & $1.82 \pm 0.09$ & $2.15 \pm 0.10$ & $2.40 \pm 0.29$ \\
\hline $\mathbf{Z n}(\mu \mathrm{g} / \mathrm{dl})$ & $7.06 \pm 5.55$ & $3.85 \pm 1.67^{*}$ & $10.97 \pm 3.09$ \\
\hline
\end{tabular}

$* \mathrm{P} \leq 0.05$ Significant $* * \mathrm{P} \leq 0.01$ Highly significant 
In canine dirofilariasis values of ESR, reticulocyte, thrombocyte, total and differential leucocytic counts were significantly increased (Hashem and Badawy, 2008). Low grade non-regenerative anaemia (10\%-60\% cases), neutrophillia (20\%-80\% cases), eosinophilia (85\% of cases) and basophillia (60\% of cases) are among the important haematological abnormalities reported in the dogs suffering from dirofilariasis (Calvert et al., 1999; Schaer, 2003). However, monocytosis is the inconsistent findings in dogs infected with $D$. immitis (Nelson and Couto, 2003). Mechanical destruction of RBCs causes anemia, hemoglobulinemia, and hemoglobinuria (Sodicof, 1995).

The biochemical parameter for two different circulating microfilariae in the present study (Table 2 ) indicated highly significant $(p \leq 0.01)$ increase in the mean value of TP and globulin in both the groups as compared to control. Hypoproteinemia might be attributed to increase in the globulin concentration as a defensive response of animal body to parasitaemia and release of hemoglobin from destructed erythrocytes (Moustafa et al., 1991; Schaer, 2003). Increased enzymatic activity along with hypergammaglobinaemia and hypoalbuminaemia was recorded in dogs suffering from dirofilariosis (Quinn et al., 1998). Increased serum protein level as evidenced in the present investigation also has been reported earlier (Moustafa et al., 1991; Hashem and Badawy, 2008). The observed hypoproteinemia could be attributed to either increased gamma globulin concentration (Schaer, 2003) in response to parasitic antigen or release of hemoglobin from the fragile RBC's and the later was further confirmed by an increase in MCV and decrease in Hb level. Non significant increase in total cholesterol concentration was recorded in both the groups in the present study. Heartworms accumulate in the right atrium or tricuspid valve area, and or posterior vena cava increases venous pressure in the liver, causing damage to the liver parenchyma (Jagannath and Ananda, 2001). Liver dysfunction causes a decreased esterification of serum cholesterol, thus increases cholesterol content of the red blood cell membranes resulting in red blood cell fragility.

Serum mineral estimation recorded significant $(\mathrm{p} \leq 0.01)$ decrease in $\mathrm{Zn}$ and increase in $\mathrm{Ca}$ concentration in $D$. reconditum group whereas similar non significant changes were recorded in D. immitis group. It might be due to presence of worms in animal body causing reduction in food intake by the dog which further leads to imbalance of different minerals in the animal body. A significant decrease in the serum level of copper, iron and zinc was observed in the animal infected with the microfilaria (Sharma and Pachauri,1982). Calcium a macro mineral and is supplied from different storage pools of the body into blood circulation, hence its level is difficult to be found deficient in blood.

It may be concluded that hemato-biochemical alterations and mineral level changes in dogs infected with filariasis are useful in assessing the disturbances in hemodynamics of the affected dogs.

\section{References}

Ananda, K.J., P.E. D'Souza and Jaganath, M.S. 2006. Methods for identification of microfilaria of Dirofilaria repens and Dipetalonema reconditum. J Vet. Parasitol., 20: 45-47.

Calvert, C.A., C.A. Rawlings and McCall, J.W. 1999. Canine heartworm disease. In: Fox, P.R.; Sisson, D. and Moise, S.N. (ed), Textbook of Canine and Feline cardiology. Philadelphia, W.B. Saunder. pp. 702-26.

Cardoso, L., C. Mendao and Madeira de Carvalho, L. 2012.cPrevalence of Dirofilaria immitis, Ehrlichia canis, Borrelia burgdorferi sensu lato, Anaplasma spp. and Leishmania 
infantum in apparently healthy and CVBDsuspect dogs in Portugal-a national serological study. Parasit. Vectors, 5: 62.

Castillo, A. and Guerrero, O. 2006.Tecnica de concentración para microfilarias (en sangre). In: Castillo A, Guerrero O, editors. Tecnicas de diagnosticoparasitologico. San Jose, Costa Rica: Editorial de Universidad de Costa Rica. pp. 74-5.

Devi, S., M.C. Sharma, R.P. Singh, U. Dimri, A.C. Patel, K. Pankaj and Singh, R.D. 2017. Effect of mineral supplementation on humoral immunity against rabies vaccine in dog pups. Indian J. Anim. Res., 52: 615-618.

Hashem, A.M. and Badawy, A.I.I. 2008. Blood cellular and biochemical studies in canine dirofilariasis. Res. J. Ani. Sci., 2: 128-134.

Jagannath, M.S. and Ananda, K.J. 2001. Heart worm diseases in dogs. Training Programme on Canine and Feline Parasites- their Control and Zoonotic Impact held at Centre of Advanced Studies, Department of Parasitology, Hebbal, Bangalore, India. $18^{\text {th }}$ to $27^{\text {th }}$ September 2001.

Kramer, L.H. 2009. Pathogenesis of dirofilaria spp. infections, in proceedings of second European dirofilaria days, 16-18 September. Morchon, R., Simon, F., Montoya, J.A., Genchi, C., Eds. Salamancajew4dhv, Spain. pp. 116-123.

McCall, J.W., C. Genchi, L.H. Kramer, J. Guerrero and Venco, L. 2008. Heartworm disease in Animals and Humans. Ad. Parasitol., 66: 193-285.

Miyoshi, T., H. Tsubouchi, A. Iwasaki, T. Shiraishi, K. Nabeshima and Shirakusa, T. 2006. Human pulmonary dirofilariasis: A case report and review of the recent Japanese literature. Respirology, 11: 343-347.
Moustafa, A.M., B. Agag, M. Esmat and Selim, A.M. 1991. Studies on filariasis in Egyptian buffaloes. III. Clinical observations and electrophoretic patterns sera of naturally infested buffaloes with microfilaria before and after treatment with stipophon. Zagazig Vet. J., 19: 583 - 595.

Nelson, W.R. and Couto C.G. 2003. Small Animal Internal Medicine.Mosby, St Louis Missouri USA.

Quinn, P.J., W.J.C. Donnelly, M.E. Carter, B.K.J. Markey, P.R. Torgeson and Breathnach, R.M.S. 1998. Microbial and parasitic diseases of $\operatorname{dog}$ and cat. W.B.Saunders London. pp. 267-271.

Schaer, M. 2003. Clinical medicine of the dog and cat. Manson, London.

Seiler, G.S., T.J. Nolan, E. Withnall, C. Reynolds, J.B. Lok and Sleeper, M.M. 2010. Computed tomographic changes associated with the prepatent and early patent phase of dirofilariasis in an experimentally infected dog. Vet. Radiol. Ultrasound, 51(2): 136-140.

Sharma, M. C. and S. P. Pachauri. 1982. Blood cellular and biochemical studies in canine dirofilariasis. Vet. Res. Comm., 5: 295-300.

Sharma, M. C., N.N. Pathak, N. N. Hung, H.T. Than and Vun, N.V. 1985. Prevalence of various parasitic infections in Murrah buffaloes in Vietnam. VI National Congress of Parasitology, held at G.B.Pant University, Pantnagar, March 19 to 21, 1985. (Abstract: D9).

Sodikoff, H.C. 1995. Laboratory Profiles of Small Animal Diseases, Mosby, United States of America.

\section{How to cite this article:}

Jaydip R. Patel, Sarita Devi, Varshney, J.P., Raval, S.H., Sarviya, V.N. and Jadhav, K.M. 2018. Haematobiochemical and Mineral Level Changes in Microfilaraemic Dogs. Int.J.Curr.Microbiol.App.Sci. 7(08): 4828-4832. doi: https://doi.org/10.20546/ijcmas.2018.708.508 